\title{
Kamuə Female Personal Names and Identity in Cultural Contexts
}

\author{
John Peter Wappa ${ }^{\circledR}$, Richard Sylvester Wada \\ Department of English Language Education, College of Continuing Education, Adamawa State Polytechnic, Yola, Nigeria \\ Email: wappajp@gmail.com,wadarichard@gmail.com
}

How to cite this paper: Wappa, J. P., \& Wada, R. S. (2019). Kamuə Female Personal Names and Identity in Cultural Contexts. Open Journal of Modern Linguistics, 9, 104-114.

https://doi.org/10.4236/ojml.2019.92011

Received: January 20, 2019

Accepted: April 27, 2019

Published: April 30, 2019

Copyright $\odot 2019$ by author(s) and Scientific Research Publishing Inc. This work is licensed under the Creative Commons Attribution International License (CC BY 4.0).

http://creativecommons.org/licenses/by/4.0/

\begin{abstract}
The study investigated the Kamuə female personal names as socio-cultural identity of the Kamuə people using the anthroponomastic framework. Sampling of about 72 participants and 12 domiciles of elders is interviewed from 12 villages to collect data for the study. The study was able to identify various types of female personal names of the Kamus people to include birth order names, female twins names, circumstantial Kamus female names and the Kamuə maiden personal names. In addition, they are mostly sentential and proverbial in nature except for the birth order names. They display the historical and socio-cultural identity of the Kamuə people and the Kamuə language.
\end{abstract}

\section{Keywords}

Kamuə, Personal Names, Maiden Names, Socio-Cultural, Identity, Higgi, Onomastics

\section{Introduction}

The present study of names is considered from the African perspective especially that of the Kamuo people as they value their culture, language and communication as expressed in their naming patterns. Name in most cases is often used to refer a term which people use to refer to anything, either animate or inanimate. They are used to identify persons, places or things, and are equally regarded as historical witnesses as well as cultural artefacts. In Africa, names are mostly linked to people's family genealogy, culture, language, occupation, and town; it is also a linkage between the physical and spiritual states, and as well serves as a means of passing information to others as it is a wide source of information (see Jauro, Ngamsa, \& Wappa, 2013; Aleksiejuk, 2014; Ennin \& Nkansah, 2016). 
The term Kamuə refers to both the people and the language. They are popularly known and referred to as Higgi, both the people and the language as well. It has about eight (8) dialects: Nkaffa, the central dialect, Dakwa, Sena, Ghye (Zah), WulaFutu, Tili Pte, Kapsiki (Ptseke) in Cameroun and Falikiria (Barrett et al., 2001; Samaila, 2004; Osaji, 1979). While FaliKiria is excluded by Mohrlang (1972), and included the Mde dialect instead, and no reason was given for the exclusion. African language classification, as done by Greenberg (1963) fall into four (4) phyla: Afro-Asiatic, Nilo-Sahara, Niger-Kordofanian and Khosian, in which Kamuə was classified as a member of the Bata-Marghi groups, and is traced to Chadic, and then to central Chadic under group A as shown in Figure 1.

The female personal naming patterns are some of traditions that the Kamuə people may never part ways with, even with the coming of Christianity to the Kamuə land. The Kamuə people employ various strategies to promote indigenous female personal names. It is highly valued considering its significance to them. Every person and every language in Africa has a personal name, the Kamuə personal female names are worth studying because of its rich linguistic and historical value. Africans "idiomatically and idiosyncratically celebrate their gift of a child in the traditional way through naming" (Mashiri, Chabata, \& Chitando, 2013).

\section{Theoretical Framework}

Onomastics is a branch of semantics that studies the etymology of names (Crystal, 1997; Al-Zumor, 2009), while anthroponomastics is its branch which deals with the study of personal names. It is concerned with the values and ideas of a society by presenting some facts about the origin, the tradition and the people's social rank. Therefore, the strong bond between the people's language and their

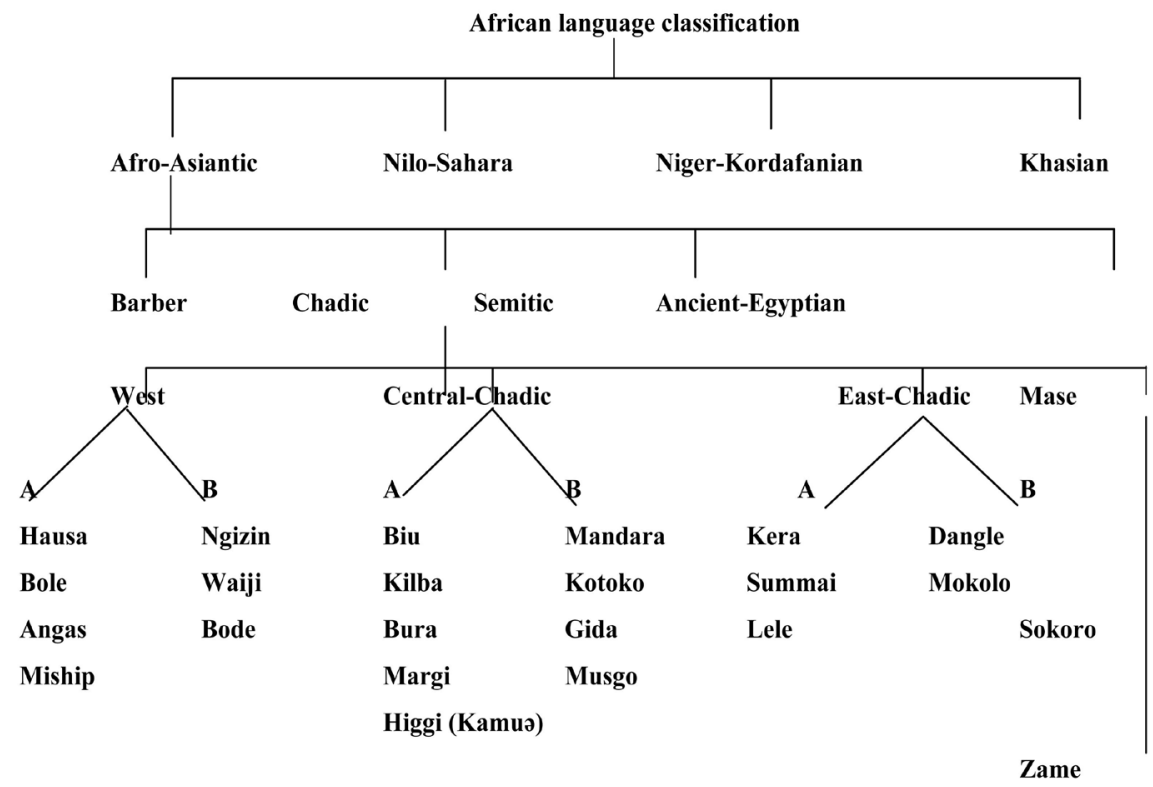

Figure 1. Source: Greenberg (1963). 
cultural practices is revealed. A society is better understood by knowing its culture, tradition, religion etc, and complete societal activities are displayed through the bond between the language and the culture, as the two are inseparable. Names to an extend reserve the culture and history of a people (Tsefaye, 2011). Anthroponomastics can be used as a general framework in specific socio-cultural contexts. Therefore, personal names can be analysed by combining different frameworks such as anthropological, linguistics and philosophical together (Alford, 1988).

\subsection{Names and Identity in Cultural Contexts}

Names are generally considered as identities or labels as well as the history of the people which are expressed in different ways such the events or circumstances surrounding such tagging or labelling (Wappa \& Abanga, 2013; Jauro, Ngamsa, \& Wappa, 2013; Onumajuru, 2016). Naming, according to Alderman (2016) is a powerful vehicle which is used for promoting identification of one's past and trying to locate oneself within the wider networks of memory. It is therefore a cultural practice that is noteworthy which has the ability to create a sense of continuity over time through its capacity for changing and challenging lines of identity. Therefore, they are chosen carefully with special care and consideration to the traditional meaning of the names being emphasised with the African naming system and intention. Meanwhile, in Africa, the name is the person him/herself and not just called by the tag. The ideological realities of the society are reflected in their naming practices. It identifies a person, legitimising a decision as well as reflecting the power of spoken words. Naming, being a linguistic act is closely linked to a people's way of lives through their values, traditions, hopes, fears and events. The preferences of the givers or the bearers of names reveal real life actions, features and beliefs. In addition, they reflect creativity and idiosyncratic nature (Saarelma-Maunumaa, 2003; Al-Zumor, 2009; Mashiri, Chabata, \& Clitanda, 2013). From Koopman (1989) perspective, in Africa, names are derivationally created from different common word classes such as nouns, verbs etc. They are used often as non-referring expressions. It should be noted that there is clear-cut between common nouns and proper nouns in the naming process. Therefore, names are composed of many lexical names where sentences are clipped to form names (Lehrer, 1992; Wappa \& Abanga, 2013).

\subsection{Personal Naming Practices}

Personal naming practices of any community reveal its social and cultural type of life. Therefore, the categorization of the child and the name-giver provides a lot of important information on the circumstances surrounding the child's birth when the name is assigned. Enormous symbolic power is contained in the words used to identify the bearer, and at the same time, it can be a message, a prayer for either the child, the community or the parents, expression of hope either cultural or traditional. Personal names are expected to serve as identifiers to an entity, and so be able to single out many similar types, especially those that are 
closely associated with what it signifies (Ullmann, 1962; Al-Zumor, 2009). In addition, they are aimed at being used to refer to the bearer as well as show the person's unique identity. Therefore, it does not describe the bearer but via the dixies in a context of direct acquaintance (Harrison, 1979). Furthermore, personal names are regarded or used as powerful symbols which are used as tools for communication. The meaningfulness of communication is when the right instrument is used and the right language, through either speaking, writing or even para-linguistics such as the sign language. Being meaningful means, being able to use words or sentences to pass the intended meaning (Lyons, 1977; Crystal, 1997). Every language has personal names which form a chunk of its vocabulary considering its linguistic features which could be such as phonology, morphology, syntax, orthography and semantics (Al-Zumor, 2009; Wappa \& Abanga, 2013).

One's identity is therefore embedded in a person's culture and tradition. Identity should not be seen as a process which is already assumed to be accomplished facts according to Hall (1989) but a production which is always in process of being constituted within representation. Looking at culture, it can be considered in terms of that commonality which people share. People's cultural codes provide "one people" who have stable, unchanging and continuous frames of reference and meaning beneath the shifting division and changes of the actual history. Cultural identity belongs to the future as much as to the past. They are points of identification within the discourses of history and culture. Therefore, the term culture can mean to refer to a whole human culture or specific culture. Culture and society, they exist together as counterparts. It should be noted that it is the unique aspect of human and should be seen as a sort of social inheritance. Culture is also a mental map which is shaped by a number of people to create relationship with their surrounding as well as with other people (Hall, 1989; Saarelma-Maunumaa, 2003). Personal name therefore are cultural and universal to all societies and serve as individuals' identities, and symbolise them individually and in different ways. They tell the society who the bearers are as well as tell the persons who they are or expected to be. They legitimatise the bearers as group members as they are able or capable of categorising people and differentiating them. The bearers are given social identities by the personal names. Concerning other studies to best of our knowledge, none has investigated Kamuə female personal names and identity in cultural contexts, hence the need for this study. It is therefore aimed at examining the identity of Kamuə female personal names in cultural contexts.

\subsection{Research Questions}

This investigation is expected to fine answers to the following research questions:

1) What are the historical links between Kamuə personal female names and the Kamuo history?

2) What are the semantic and cultural implications of the Kamuə female per- 
sonal names?

\section{Methods}

\subsection{Participants}

The participants of this study are strictly the Kamuə people of Michika local government area of Adamawa state, Nigeria. Considering the numerous nature of the Kamuo dialects, the Nkaffa dialect which is central (Mohrlang, 1972; Samaila, 2004) was used for this study. About seventy-two (72) participants were drawn from twelve (12) villages, which included Trimadzi, Yambule, Shikwinaira, Yamue, Thluri, Kubi, Munne, Lughu, Yasukule, Kwadzale, Madzi and Nkafamiya, and twelve (12) domiciles of elders were selected and interviewed using an opened-ended question. Equal number of six (6) for each gender was selected.

\subsection{Procedure}

Qualitative research method was adopted to analyse the subjective opinions of the participants on the cultural and historical importance of the Kamuə personal female names as identity of the Kamuə socio-cultural life. Therefore, interpretive analysis was an integral process, as that will give the cultural realities of these names. Data collecting instruments were questionnaires used to collect names, and unstructured interview which was conducted purely in Kamuə language using the Nkaffa dialect and was recorded with the knowledge of the participants. The ethics requirements were highly adhered to in the process.

\section{Data Analysis and Presentation of Result}

\subsection{The Kamuə Female Personal Names}

The Kamuə female personal name as it is with any other societal personal name is a word or group of words, often used by people to identify a particular person or individual and they are based on the cultural and traditional formations. The history and values of the society are reflected in them. Personal names are said to reflect the sociology and the psychology of the era in which they are or were used (Jauro, Ngamsa, \& Wappa, 2013). This study identified four (4) major categories: the Kamuə Female birth order names, Kamuə Female twins names, Kamuə Female circumstantial names and Kamuə maiden names.

\section{The Kamuə Female Birth-Order Names}

The birth order name as far as the culture and tradition of the Kamuə people is concerned, a child has a name before he or she is even conceived in the womb. That is to say, any other name given to any Kamuə child is an addition to the birth order name s/he has at birth. Name of the bearer in indicates his or her birth position. The counting or the positioning is according to the number of children the mother gave birth to and not that of the father, as he can marry more than one wife traditionally. Therefore, choosing of the names is influenced 
by the child's birth position.

$\begin{array}{ll}\text { Birth Position } & \text { Female Birth-Order Name } \\ \text { First born } & \text { Kúvè } \\ \text { Second born } & \text { Másí } \\ \text { Third born } & \text { Kwárámbá } \\ \text { Fourth born } & \text { Kwányè } \\ \text { Fifth born } & \text { Kwájí } \\ \text { Sixth born } & \text { Kwátá } \\ \text { Seventh born } & \text { Kwásiní } \\ \text { Eighth born } & \text { Kwádà } \\ \text { Ninth born } & \text { Dràmbí } \\ \text { Tenth born } & \text { Kwátrì }\end{array}$

The birth order names from number 1 to number ten have fixed names, within which four are unisex names, these are Kwaji, Kwada, Drambi and Kwarti. Then, any child given birth to after the tenth, the naming is done by adding the suffix - "hálá" to the birth order name starting with the first, indicating that the mother gave birth to the child at her old age. They can be considered as derivational names from other names, that is, derived from the birth order names. However, it is not too common these days to fine women who have gone beyond ten. The examples of such names are:

$\begin{array}{ll}\text { Birth Position } & \text { Female Birth-Order Name } \\ \text { Eleventh born } & \text { Kúvèháló } \\ \text { Twelfth born } & \text { Másíhálá } \\ \text { Thirteenth born } & \text { Kwárámbáhálá } \\ \text { Fourteenth } & \text { Kwányèhálá } \\ \text { Fifteenth } & \text { Kwájíhálá }\end{array}$

\subsection{The Kamuə Female Twins' Names}

As it is with any other society, especially in Africa, twins have a special naming pattern. Every community has different patterns of naming her twins. In the Kamuə community, the twins are named based on how they were delivered, that is, their birth positions. The first, "Tlákámá" is unisex, that is, neuter gender name while the remaining are sex-specific.

$\begin{array}{ll}\text { Birth Position } & \text { Name } \\ \text { First } & \text { Tlákámá } \\ \text { Second } & \text { Kwálghà } \\ \text { Third } & \text { Kwágwè }\end{array}$

\subsection{Circumstantial Female Personal Names}

This category of Kamuə female names constitutes a good chunk of the Kamuə female names. They are names given to the female children based on the circumstances or events surrounding their birth or that which occurred at the time of their birth, as well as the experiences of the name giver (Ogunwale, 2012; En- 
nin \& Nkansah, 2016). Invariably, they serve as a social and historical store for the Kamuə people. Based on the events during the child's birth, a situation or a certain historical event is remembered. These are some Kamuə common identities. This falls into four (4) categories.

\subsubsection{The Kamuə Female Born during Certain Events}

This category of names contains names that indicate certain events related to the time of the children's birth. Certain event occurred at time of birth of such children, therefore, such issues form part of their names, and sometimes the mother's peculiar habits too can contribute to the giving of such names as seen below:

$\begin{array}{ll}\begin{array}{l}\text { Name } \\ \text { Kwájíbàdlò }\end{array} & \begin{array}{l}\text { Gloss } \\ \text { fifth born unisex name given to a child given birth to } \\ \text { on the day his/her mother sales her local beer. } \\ \text { fifth born unisex name for the child who suffered a se- } \\ \text { Kwájíghwì }\end{array} \\ \text { vere fire burn. } \\ \text { Wwádèméshì } & \begin{array}{l}\text { born shortly before/after the death of a grandparent } \\ \text { the mother ate a lot of tilapia fish when she was carry- } \\ \text { ing her pregnancy. } \\ \text { Másínkwà }\end{array}\end{array}$

\subsubsection{The Kamuə Female Names Expressing Hope in God}

Names in this category are given to children when the parents might have experienced some negative feelings before the birth of the child, the family might have suffered some sort mockery or insult from some members of the community. The names express their hope in God and acknowledging His supremacy.

$\begin{array}{ll}\text { Name } & \text { Gloss } \\ \text { Mdígléná } & \text { is my life under human control? } \\ \text { Wámdívò } & \text { who do(es) they/ he/she have/has? } \\ \text { Lə̀métà } & \text { the Lord is with us } \\ \text { Mdípàná } & \text { is it man that created the child? }\end{array}$

4.3.3. The Kamuə Female Personal Names Related to Facial Appearance This category of Kamuə female names are driven from certain facial appearance of the baby at birth, such as the colour of the skin, "beá"-white, "ngòlyò"-black, "ghə̀a"-red, the head "ghì" size, etc. these all reflect the culture as well as the identity of the Kamuə people as it relates to their female naming patterns.

\begin{tabular}{|c|c|}
\hline Name & Gloss \\
\hline Kwájíghì & fifth born unisex name given to a child born with big hea \\
\hline Másíghì & second born female child born with big head. \\
\hline Kwádàbeá & $\begin{array}{l}\text { unisex name for eight born child born with extra fair } \\
\text { complexion at birth. }\end{array}$ \\
\hline Wzhàngə̀lyə̀ & a girl child having a black skin complexion at birth. \\
\hline Wzhàbeá & a girl child born with extra fair skin complexion at birth. \\
\hline Kwásìníghòa & seventh born female with pale skin complexion at birth \\
\hline
\end{tabular}


Kwájíbwà fifth born unisex name for the child born big (Beyond normal baby weight).

\subsubsection{The Kamuə Female Names Are Made to Pass Message}

The Kamu names, in this case, the female personal names are formed in a manner in which they are used as vehicles for sending messages. Considering certain circumstances that the givers or parents might have experienced in their lives, give names that will either serve as answers to assumed questions which people might have asked directly or indirectly, rhetorical questions or make some blanket statements without necessarily mentioning names. Such names come in the form of interrogatives, sentences, statements or sometimes just a word or a phrase (see Onumajuru, 2016; Ogunwale, 2012).

$\begin{array}{ll}\text { Name } & \text { Gloss } \\ \text { Wzhàvə̀ná } & \text { do they have daughter? } \\ \text { Gə̀hyá } & \text { let them say what is in their mind. } \\ \text { 'ìmyéwà } & \text { you should dislike/hate me if you wish. } \\ \text { Gwàréndzá } & \begin{array}{l}\text { living/staying together with all sorts of people. } \\ \text { Màgwà }\end{array} \\ \text { Wyégə̀ } & \text { worthless noise. } \\ \text { Wávàcá } & \text { do not mind/forget what people say. } \\ \text { Kàsháwà } & \text { you should/can continue. }\end{array}$

\section{The Kamuə Maiden Names}

This category of name is a sort of Bynames because the bearers already have their birth order names and either baptismal or circumstantial names in addition which they use as official names. This category of names is never used as official names or appear on any official document, but highly honoured in the family and among the elders. The Kamuə people refer to such names as "Tlír mwòmpwé". Literally, it means "corn mill name(s)" because it is given to the bearer after she might have presented some gifts, including corn mill as the major gift, to the mother-in-law and the father-in-law. Then the father-in-law gives a name, most at times, in proverb, and in the absence of the father-in-law, the mother-in-law gives the name. These names are given only to young women who are newly married. These are given names other than the birth order names or circumstantial names, though they could be circumstantial, in the sense that such names are given based on the situation/condition or circumstances of the family the woman is married into. The names are usually or normally proverbial in nature.

$\begin{array}{ll}\text { Names } & \text { Gloss } \\ \text { Wáwsívàhyá } & \text { do they have anything? } \\ \text { Wsívàhyáná } & \text { what do they have? } \\ \text { Wáhyáré } & \text { who are they? } \\ \text { Wángə̀rká } & \text { who gave him/her? } \\ \text { Wávòcó } & \text { forget what people say or do not mind what people say. }\end{array}$




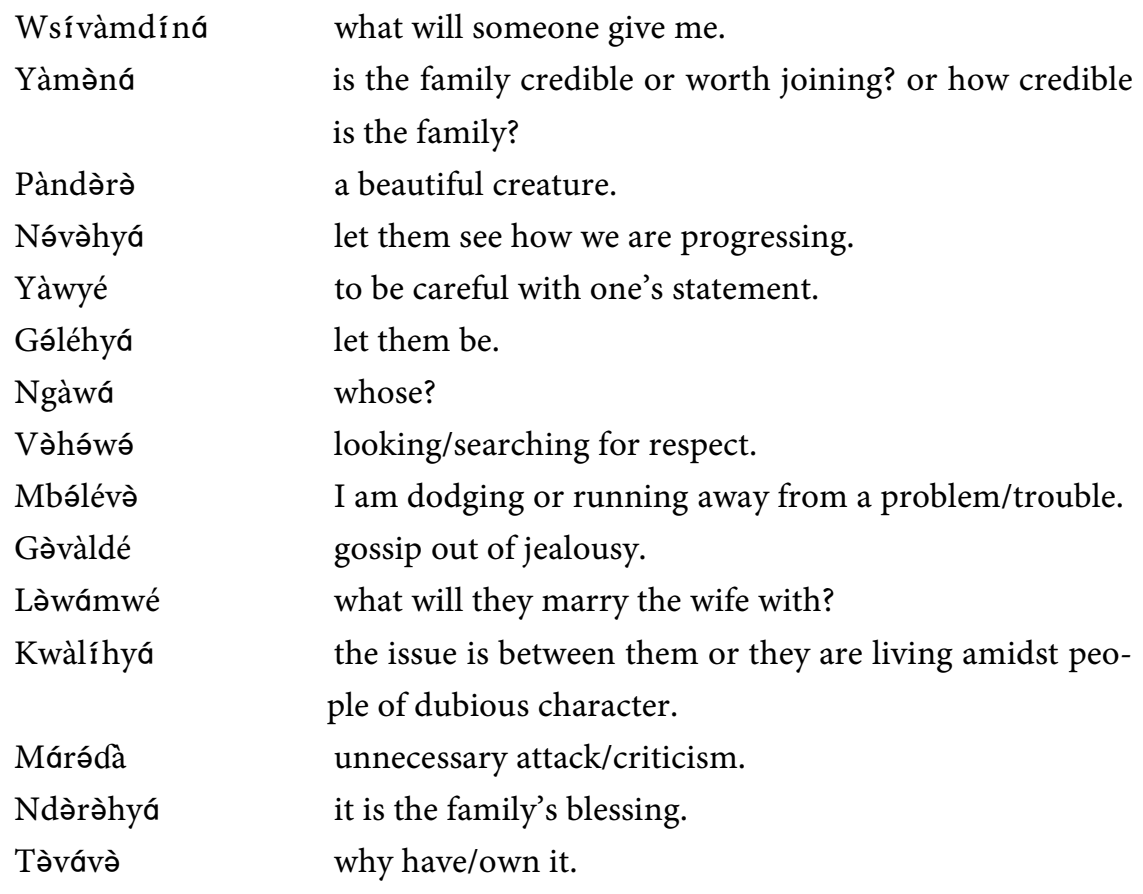

The Kamuə female maiden names reflect the feeling of the family she is married into. The givers of such names state what is in their mind or try to tell the world how the family is perceived by the society or by certain individuals, and their assumed reply to people's perceptions of them. Therefore, some the names serve as answers to questions either directly or indirectly directed to the family. Names such as Lòwámwé, Wsívàhyáná, Tàvávò, Lòwámwé, Ngàwáetc are presented in interrogative forms assumed questions which the enemies of the family are asking about the financial status, societal status, respect, honour etc. of the family. Therefore, the names try to show to the members of the community that never liked them or those that have underrated their capabilities of doing what is assumed they cannot do, so, proving the enemies wrong.

\section{Conclusion}

The Kamuə female personal names are names given to the bearers by the parents in the case of newborn babies and father-in-law or mother-in-law in the case of the maiden names. All these names confirm with the traditional and cultural identities of the Kamur people as displayed in their day-to-day life. These names come in all forms and structures, expressing the experience of the family, the name givers or the child (Ogunwale, 2012). Some of the names too express hope, prayer and wish. The Kamuə names are mainly in sentence, interrogative or single word as it is with other African naming patterns. Naming practices in African societies, including Kamuə, often reflect socio-cultural and ideological realities of the societies (Mashiri, Chabata, \& Chitando, 2013; Ennin \& Nkansah, 2016). The Kamuə female personal names generally, are sentential in nature as in the case of Onumajuru (2016). As language is inseparable from culture (Genc \& Bada, 2005; Tum, Kunt, \& Kunt, 2016), so it is with the Kamuə female per- 
sonal names with the Kamuə cultural identity. Meanwhile, the Kamuə female personal names are generally proverbial in nature except in the case of birth order names.

\section{Conflicts of Interest}

The authors declare no conflicts of interest regarding the publication of this paper.

\section{References}

Alderman, D. H. (2016). Place, Naming and the Interpretation of Cultural Landscapes. In B. Graham, \& P. Howard (Eds.), The Ashgate Research Companion to Heritage and Identity (pp. 195-213). Boca Raton, FL: CRC Press.

https://s3.amazonaws.com/academia.edu.documents/6337178/placename_heriage_capt er.pdf?AWSAccessKeyId=AKIAIWOWYYGZ2Y53UL3A\&Expires=15475511\&Signatu re=Z0ZjH6pDnJlUzzveCKirQH6bgao\%3D\&response-contentdisposition=inline $\% 3 \mathrm{~B} \%$ 20filename\%3DPlace_Naming_and_the_Interpretation_ofzC.pdf

Aleksiejuk, K. (2014). Internet Names as an Anthroponomastic Category. Annex Secció, 3, 243-255.

Alford, R. D. (1988). Naming and Identity: A Cross-Cultural Study of Personal Naming Practices. New Haven, CT: HRAF Press.

Al-Zumor, A. Q. G. (2009). A Socio-Cultural and Linguistic Analysis of Yemeni Arabic Personal Names. GEMA Online Journal of Language Studies, 2, 15-27. http://ejournal.ukm.my/gema/article/view/155/131

Barrett, D.B. et al. (2001) World Christian Encyclopedia (2nd ed., pp. 162-231).

Crystal, D. (1997). The Cambridge Encyclopaedia of Language (2nd ed.). Cambridge: Cambridge University Press.

Ennin, T. P., \& Nkansah, N. B. (2016). A Literary Anthroponomastics of Three Selected African Novels: A Cross Cultural Perspective. International Journal of Society, Culture \& Language, 4, 69-79.

http://www.ijscl.net/article_17784_3475e7cbec2e89e011eb77526efeb740.pdf

Genc, B., \& Bada, E. (2005). Culture in Language Learning and Teaching. The Reading Matrix, 5, 73-84. http://www.readingmatrix.com/articles/genc_bada/article.pdf

Greenberg, J. H. (1963). The Languages of Africa. Bloomington, IN: Indiana University Press.

Hall, S. (1989). Cultural Identity and Cinematic Representation. Framework: The Journal of Cinema and Media, 36, 68-81. https://www.jstor.org/stable/44111666

Harrison, B. (1979). An Introduction to the Philosophy of Language. London: The Macmillan Press.

Jauro, L. B., Ngamsa, J., \& Wappa, J. P. (2013). A Morphosemantic Analysis of the Kamue Personal Names. International Journal of English Language and Linguistics Research, 1, 1-12. http://www.ea-journals.org

Koopman, A. (1989). The Aetiology of Zulu Personal Names. Nomina Africana, 3, 31-46.

Lehrer, A. (1992). Names and Naming: Why We Need Fields and Frames. In A. Lehrer, \& E. F. Kittay (Eds.), Frames, Fields, and Contrasts New Essays in Semantic and Lexical Organization (123-140). New York: Routledge, Taylor and Francis Group.

Lyons, J. (1977). Semantics. Cambridge: Cambridge University Press. 
Mashiri, P., Chabata, E., \& Chitando, E. (2013). Postcolonial Christian Naming Practices in Zimbabwe. Journal for Studies in Humanities and Social Sciences, 2, 163-173. http://repository.unam.na/bitstream/handle/11070/1401/Mashiri_postcolonial2013.pdf ?sequence $=1$ \&isAllowed $=\mathrm{y}$

Mohrlang, R. (1972). Higi Phonology Zaria. Centre for the Study of Nigerian Languages.

Ogunwale, J. A. (2012). A Pragmalinguistic Study of Yoruba Personal Names. Journal ofLiterary Onomastics, 2, 24-35. http://digitalcommons.brockport.edu/jlo/vol2/iss1/4

Onumajuru, V. C. (2016). A Semantic and Pragmatic Analyses of Igbo Names. Africa Research Review, 10, 307-324. https://doi.org/10.4314/afrrev.v10i2.21

Osaji, B. (1979). Language Survey in Nigeria. Centre international de recherche sur le bilinguisme imprimé an Canada.

Saarelma-Maunumaa, M. (2003). Edhina Ekogidho-Names as Links: The Encounter between African and European Anthroponymic Systems among the Ambo People in Namibia. An Unpublished Ph.D. Thesis, Helsinki: Faculty of Arts, University of Helsinki.

https://helda.helsinki.fi/bitstream/handle/10138/19661/edhinaek.pdf?sequence=1Laha

Samaila, Z. (2004). The Social History of the Higgi People. Lagos: Emmatola Nigeria Limited.

Tsefaye, G. (2011). Semantics and Pragmatics of Oromo Personal Names. Lambert Academic Publishing.

Tum, D. O., Kunt, N., \& Kunt, M. (2016). Language Learning in Conflictual Contexts: A Study of Turkish Cypriot Adolescents Learning Greek in Cyprus. Language, Culture and Curriculum, 29, 207-224. https://doi.org/10.1080/07908318.2015.1136322

Ullmann, S. (1962). Semantics: An Introduction to the Science of Meaning. Oxford: Basil Blackwell.

Wappa, J. P., \& Abanga, A. (2013). An Onomastics Perspective of Kamue Proper Names, Harsunan Nijeriya (Volume 23, Special Edition). 